\title{
DIALECTS OF VULGAR LATIN AND THE DIALECTAL CLASSIFICATION OF THE ALPS-DANUBE-ADRIA REGION ${ }^{1}$
}

\begin{abstract}
Summary: This study compares the Vulgar Latin Raetia, Noricum, Venetia et Histria, Pannonia Superior, Pannonia Inferior and Dalmatia with each other and their provincial capitals in relation to the hypothesized large dialectal isoglosses of Vulgar Latin, and in turn, to the modern Romance languages located in those areas, such as Western Romance, Northern Italian, Southern Italian and Eastern Romance dialects. The analysis is done on the palatal and velar vowels, the V B merger, intervocalic V drop, sonorization, degemination, assimilation, palatalization and final /-s/ drop. The territories of the Alps-Danube-Adria region will be classified according to their similarities to each other and their similarity to the Vulgar Latin or Romance dialects.
\end{abstract}

Key words: vulgar Latin, dialectology, regional diversification, phonology, inscriptions

This study is dedicated to the memory of József Herman who in 1983 first introduced ${ }^{2}$ the idea of examining the possibility of a Vulgar Latin isogloss in the provinces of the Alps-Danube-Adria region, based on the historical analysis of Jürgen Untermann's study. 35 years later, this study is the first attempt ${ }^{4}$ to analyze all of the

\footnotetext{
${ }^{1}$ The present paper was prepared within the framework of the project NKFIH (National Research, Development and Innovation Office) No. K 124170 entitled "Computerized Historical Linguistic Database of Latin Inscriptions of the Imperial Age" (see: http://lldb.elte.hu/) and of the project entitled "Lendület ('Momentum') Research Group for Computational Latin Dialectology" (Research Institute for Linguistics of the Hungarian Academy of Sciences).

${ }^{2}$ HeRMAN, J.: Le latin dans les provinces danubiennes de l'Empire romain. Problemes et perspectives de la recherche. In ANRW II.29.2 (1983) 1089-1106 (= HERMAN, J.: Du latin aux langues romanes. Études de linguistique historique réunies par Sándor Kiss avec une préface de Jacques Monfrin. Tübingen 1990, 164-182).

${ }^{3}$ UntermanN, J.: Alpen-Donau-Adria. In Die Sprachen im Römischen Reich der Kaiserzeit [Bonner Jahrbücher, Beiheft 40]. Köln-Bonn 1980, 45-63.

${ }^{4}$ There have been made partial attempts in our previously published studies which covered only certain territories of the Alps-Danube-Adria region, such as GONDA, A.: Changes in the consonant system of Pannonia Inferior, Dalmatia and Venetia et Histria. Graeco-Latina Brunensia 22.2 (2017) 165-181
} 
provinces of the Alps-Danube-Adria region, Venetia et Histria, Raetia, Noricum, Pannonia Inferior, Pannonia Superior and Dalmatia together as a linguistic unit according to the vision of Herman, relying on the statistical methodology devised by Herman, and using the LLDB database, conceptualized also by Herman. Untermann pointed out that the provinces of the Alps-Danube-Adria region constituted an organic and coherent social, economic and political unit within the Roman empire, and Herman proposed that this region could be a good candidate as a larger geographic area for future research in Latin dialectology, since socio-political geographical units often shape linguistic boundaries.

In this study, we are comparing all of the provinces belonging to the AlpsDanube-Adria region, and we are also contrasting the data of the provincial capitals with those of their countryside. All these results will be interpreted in the framework of the statistics of large regional samples of Vulgar Latin. In our methodology, the spelling mistakes of the inscriptions were divided between an early period of the 1st to 3 rd centuries and a late period of the 4 th to 7 th centuries, except in the case of Noricum and Raetia where I had to lower the dividing line to $250 \mathrm{AD}$ due to the sparse numbers of data from the late period. I counted for both periods those data which couldn't be dated precisely to only one of the two periods, and in the case of Noricum and Raetia, I included the data in the category labeled as "fortasse recte" in the LLDB, which are those inscriptional errors that potentially might be explained as correct. I didn't include archaic spellings which could have distorted especially the statistics related to the misspelling of velar vowels. For the examination of consonant changes, I calculated the relative frequencies of all inscriptional errors which cannot be classified as purely orthographical or technical mistakes ${ }^{5}$ of the lapicida. We must note that the number of linguistically relevant data in certain territories was very low, but we shall consider this presentation as a hypothetical evaluation of the Vulgar Latin in the Alps-Danube-Adria region.

\section{TYPOLOGY OF THE VULGAR LATIN VOWEL SYSTEM}

For the analysis of the vowel system, we take only the palatal and velar changes as these are the most significant classifiers among the vowel changes. There are three main territorial variants of how the Romance languages merged the quality of palatal and velar vowels of Vulgar Latin: the Western or Italo-Western vowel system, where both the stressed and unstressed short /i/ merged in quality with the stressed and unstressed long/e:/ and both the stressed and unstressed short /u/ merged with the stressed and unstressed long /o:/; the Eastern system, where the behavior of the /e/-/i/ vowels is the same as in the Western system, however, the stressed /o/-/u/ did not merge,

\footnotetext{
and GondA, A.: The Aquincum-Salona-Aquileia Triangle: Latin language in the Alps-Danube-Adria region. Acta Antiqua Hung. 57.1 (2017) 99-123.

${ }^{5}$ Purely orthographical misspellings are the errors like the confusion between the letters $C \sim \mathrm{K} \sim \mathrm{Q}$ and $\mathrm{X} \sim \mathrm{CS}$, and technical errors of the lapicida are errors like the carving of an $\mathrm{E}$ instead of $\mathrm{F}$.
} 
neither did the unstressed $/ \mathrm{u} /$, but the unstressed /o/ sounds, both long and short, changed to $/ \mathrm{u} / .^{6}$ There was, finally, a third system, the Sardinian, where none of these fusions happened.

The inscriptional misspellings indicating sound changes in the palatal and velar vowel system of the six provinces and their capitals can be seen in Tables 1-2. We will use another statistical analysis, the Vulgar Latin regional typology samples as our contrast samples and points of reference in the classification of our provinces. In Table 3, we provide four regional typology contrast samples which are taken from the later period (extending for a little later period, 4th-9th centuries), because that was the period when Vulgar Latin dialectal variations really started to take place. ${ }^{7}$ The data of the provinces of the Alps-Danube-Adria region are not included among the data of these regional typology samples so the characteristics of our examined provinces don't influence the statistics of the typology samples, which thus can serve as truly independent reference points. These represent four larger regions which developed four of the main Romance dialect groups: the Western Romance Vulgar Latin sample contains the palatal and velar misspellings of the Hispanian and Gallian provinces, Lusitania, Baetica, Tarraconensis, Aquitania, Lugudunensis, Narbonensis and Belgica. The Northern Italian Vulgar Latin sample contains the Italian regions of Transpadana, Liguria and Aemilia, the regions of Roman Italia north of the MassaSenigallia line, minus the Alps-Danube-Adria regions. The Southern Italian Vulgar Latin sample contains the inscriptional errors of the Italian regions south of the Massa-Senigallia line, without Rome, because Rome was a melting pot collecting various ethnicities from the empire, and I excluded it so that its cosmopolitan nature do not disturb the picture of the local southern Italian dialect. The Eastern Romance Vulgar Latin contrast sample contains the misspellings of Dacia, Moesia and Thracia.

Contrarily to our expectations, the Eastern Romance sample shows a high proportion of the stressed short $/ \dot{u} /$ misspelled as $\mathrm{O}$, but we find this value high in the Western Romance Vulgar Latin sample, as expected, and it is the lowest in the Northern and Southern Italian regional samples $(3-4 \%)^{8}$

\footnotetext{
${ }^{6}$ TAMÁS, L.: Einführung in die historisch-vergleichende romanische Sprachwissenschaft. Würzburg 1983, 45-48. Neither the unstressed /o/ nor the unstressed short /i/ changed to /u/ and /e/ in all instances, but, in the case of unstressed short /i/ $>/ \mathrm{e} /$, it is a detectable tendency in all Romance languages, and the unstressed /o/ $>/ \mathrm{u} /$ is indeed testified by the Eastern Romance languages such as Romanian and Dalmatian.

${ }^{7}$ The statistics of these four regional typology samples for velar and palatal changes were calculated from the data of the indicated provinces between the 4th-9th centuries in the LLDB according to the state of the database on 6th September, 2018. Archaisms like SERVOS $<$ servus were excluded. Data which were dated to a wider period, possibly belonging to the 4th-9th centuries but also possibly earlier, were included in the statistics in order amplify the size of the samples.

${ }^{8}$ Our two Italian regions, which are related to Eastern Romance and in some analyses they grouped together with the Eastern Romance languages, have very low proportions of stressed short /úl represented by the letter $\mathrm{O}$. This might suggest that the center of this conservative phenomenon could be Italy originally, and it seems until the collapse of the Roman empire neither the Eastern Romance nor the Western Romance vowel system took their definite forms that are now recognized as such according to the testimony of the Italian and Romanian languages.
} 

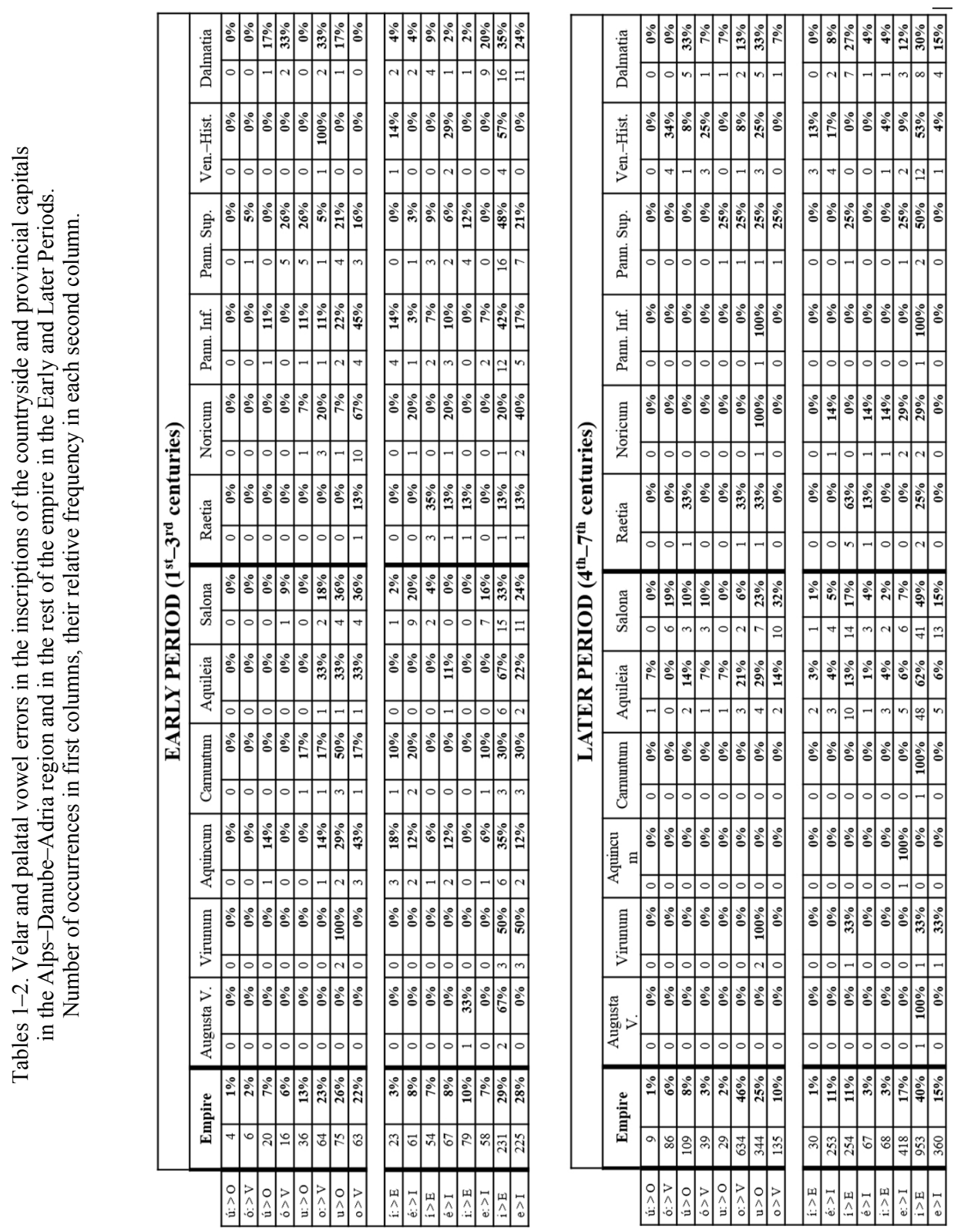
Table 3. Regional typology contrast samples of the palatal and velar vowel misspelling in inscriptions from the 4 th-9th centuries outside the Alps-Danube-Adria region. Number of occurrences in the first column, their relative percentage in the second.

\begin{tabular}{|c|c|c|c|c|c|c|c|c|}
\hline \multirow[b]{2}{*}{ ú: $>0$} & \multicolumn{2}{|c|}{ Western Romance } & \multicolumn{2}{|c|}{ Northern-Italian } & \multicolumn{2}{|c|}{ Southern-Italian } & \multicolumn{2}{|c|}{ Eastern Romance } \\
\hline & 4 & $1 \%$ & 0 & $0 \%$ & 1 & $1 \%$ & 0 & $0 \%$ \\
\hline ó: > V & 39 & $7 \%$ & 9 & $7 \%$ & 10 & $9 \%$ & 2 & $7 \%$ \\
\hline ú > O & 81 & $14 \%$ & 4 & $3 \%$ & 4 & $4 \%$ & 4 & $14 \%$ \\
\hline ó > V & 11 & $2 \%$ & 4 & $3 \%$ & 9 & $8 \%$ & 3 & $10 \%$ \\
\hline $\mathrm{u}:>\mathrm{O}$ & 10 & $2 \%$ & 3 & $2 \%$ & 2 & $2 \%$ & 2 & $7 \%$ \\
\hline $0:>V$ & 202 & $36 \%$ & 59 & $46 \%$ & 53 & $50 \%$ & 6 & $21 \%$ \\
\hline $\mathrm{u}>\mathrm{O}$ & 216 & $38 \%$ & 37 & $29 \%$ & 15 & $14 \%$ & 5 & $17 \%$ \\
\hline $0>V$ & 1 & $0 \%$ & 12 & $9 \%$ & 13 & $12 \%$ & 7 & $24 \%$ \\
\hline $\mathrm{i}:>\mathrm{E}$ & 18 & $2 \%$ & 0 & $0 \%$ & 2 & $1 \%$ & 2 & $5 \%$ \\
\hline é: $>$ I & 141 & $13 \%$ & 16 & $7 \%$ & 12 & $7 \%$ & 2 & $5 \%$ \\
\hline$i>E$ & 150 & $14 \%$ & 29 & $12 \%$ & 11 & $7 \%$ & 2 & $5 \%$ \\
\hline é > I & 21 & $2 \%$ & 4 & $2 \%$ & 6 & $4 \%$ & 2 & $5 \%$ \\
\hline $\mathrm{i}:>\mathrm{E}$ & 29 & $3 \%$ & 1 & $0 \%$ & 3 & $2 \%$ & 4 & $10 \%$ \\
\hline $\mathrm{e}:>\mathrm{I}$ & 153 & $14 \%$ & 28 & $11 \%$ & 44 & $27 \%$ & 3 & $7 \%$ \\
\hline $\mathrm{i}>\mathrm{E}$ & 474 & $43 \%$ & 149 & $61 \%$ & 64 & $39 \%$ & 11 & $26 \%$ \\
\hline$e>I$ & 109 & $10 \%$ & 18 & $7 \%$ & 21 & $13 \%$ & 16 & $38 \%$ \\
\hline
\end{tabular}

An observation which can help categorize the territories of the Alps-DanubeAdria region is that the combined number of both the stressed and unstressed $/ \mathrm{u} /$ changes to $\mathrm{O}$ is much higher, $52 \%$ in the Western Romance contrast sample than in the other typology samples (e. g. in the Southern sample these add up only to $18 \%$ ), while the unstressed $/ \mathrm{o} />\mathrm{V}$ misspelling is the most frequent in the Southern sample with $62 \%$. This dialectal unit is related to Eastern Romance, and this sum in the actual Eastern contrast sample is similarly high with its $45 \%$ (in the Western Romance sample, it's only $36 \%$ ). If we compare them by this method, these statistics represent on a plausible level of credibility what we know about the supposed Vulgar Latin palatal and velar vowel change processes.

Based on these observations, we can characterize our Eastern Romance Vulgar Latin sample as the most conservative one, having a moderate tendency of unstressed /o/, /o:/ > V type of misspelling, and a slight degree of confusion between the unstressed short $/ \mathrm{e} / \sim / \mathrm{i} / \mathrm{s}$ sounds, probably tending to closing-up direction indicated by /e/ > I spelling.

The Southern Italian sample has the strongest tendency in the misspelling of the unstressed /o/, /o:/ as V, and it also has a higher degree of confusion among the unstressed palatals, but with a preponderance of long /e:/ > I instead of the short variant that we have seen in the Eastern Romance Vulgar Latin contrast sample.

The Northern Italian stressed velars are the most conservative. The unstressed velars seem still inclined toward the $/ \mathrm{o} />\mathrm{V}$ change, but the proportion of the reverse $(/ \mathrm{u} />\mathrm{O})$ is becoming higher than the previous two samples, indicating that the direction of change probably wasn't so clear, and the stressed short $/ \dot{1} />$ E type of 
misspelling is becoming more widespread here, and the same type of error with the unstressed /e/ is prevalent: these two were the most universal and most typical Vulgar Latin phenomena, and this indicates a more advanced development toward Romance languages at the Northern Italian group.

Finally, the Western sample could be described as typically forecasting the vowel system of the Western Romance languages, with the short stressed $/ \mathrm{u} />\mathrm{O}$, $/ \mathrm{i} />\mathrm{E}$ and unstressed $/ \mathrm{u} />\mathrm{O}, / \mathrm{i} />\mathrm{E}$, but the high proportion of unstressed $/ \mathrm{o}: />\mathrm{V}$ spelling makes us think that this was more than just a hypercorrective error, and the unstressed /u/, which has typically (but not always) become more open and evolved into /o/ in Western Romance languages, hadn't yet settled its more open character in the Western Vulgar Latin between the 4th-7th centuries completely.

In all this review we can perfectly see a gradualness of the sound changes in a geographical sense of spreading from one neighboring region to the other: the stressed short $/ \mathbf{i} />E$ (and also but less clearly the unstressed /i/ $>$ E) misspelling is most frequent in the West (14\% stressed, $57 \%$ in total) and in Northern Italy (73\% in total), then it is less active in Southern Italy ( $46 \%$ in total), and it's quite rare in the East (5\% stressed, $31 \%$ in total). It may be a mark of a phenomenon spreading from Western Europe through Northern Italy to Southern Italy and from there to the East. The stressed and unstressed short $/ \mathrm{u} />\mathrm{O}$ spelling is likewise decreasing in frequency from West to East, as it is $52 \%$ in total in the Western sample group, $32 \%$ in the Northern, $18 \%$ in the Southern Italian group, and $31 \%$ in the Eastern sample, though slightly higher, still significantly less than in the West. Meanwhile, both the long and short unstressed $/ 0 />\mathrm{V}$ type of error is $45 \%$ in the Eastern sample group, $62 \%$ in the Southern Italian, $55 \%$ in the Northern, and only $36 \%$ in the Western group. Also, the /e/ > I type of misspelling seems to be more widespread in the Eastern Romance contrast sample (55\% combined) and in the Southern Italian Vulgar Latin $(51 \%$ combined), than in the Northern ( $27 \%$ combined) and Western groups ( $39 \%$ combined).

We will classify our 12 territories, the provincial rural areas and capitals according to these parameters which are set up with consideration to the statistics of the inscriptions in our four contrast sample regions and to the characteristics of the fully developed Romance vowel systems. If the ratio of /o/, /o:/ $>\mathrm{V}$ type of errors is or is above $50 \%$, we will classify the territory as Eastern velar system, if the $/ \mathrm{u} /, / \mathrm{u} />\mathrm{O}$ is or is above $50 \%$, as Western velar system, and if none of these calculations results in a clear categorization, territories with more changes to $\mathrm{O}$ than to $\mathrm{V}$ will be put into the Western velar group. In the case of the palatal vowels, since there was no significant difference in the changes of palatal system throughout the empire, we can only make a category of more advanced Romance palatal system, where the change of both the stressed and unstressed short / $\mathrm{i} /$ to $\mathrm{E}$ is advanced, and a less advanced group, where other errors are more dominant, for example the tendency to represent the original classical Latin long /e:/ sounds with the letter I, a sort of itacism that is also found in speakers of Greek background and is widespread in inscriptions either as a hypercorrection or as mark of an actual sound change. Consequently, if the ratio of $/ \mathrm{i} /$ and $/ \mathrm{i} />\mathrm{E}$ type of errors is or is higher than $50 \%$, we classify the territory as a well-developed Romance palatal system. In case the proportion of /e/, /é/, /e:/, /é:/ > I type of mistakes is or is higher than $50 \%$, then we will categorize it as 'itacizing' palatal system. 


\section{VOWEL SYSTEM IN THE ALPS-DANUBE-ADRIA PROVINCES}

According to the inscriptional mistakes in their velar systems in the early period (see Table 1), we can classify all of our territories as Eastern type, with the exception of Virunum and Carnuntum which are more reminiscent of the Western velar system, because their Western type of velar misspellings $(/ \mathrm{u} /, / \mathrm{u} />\mathrm{O})$ are or are higher than $50 \%$. Augusta Vindelicorum, Raetia, Pannonia Superior and Dalmatia are neither properly Eastern nor Western, but they are classified as Eastern type due to their lack of the Western velar characteristics.

In the later period (Table 2), if we follow this same method of classification, the picture changes greatly. Virunum remains in the Western velar system from the previous period, and Raetia, Noricum, Pannonia Inferior, Dalmatia are also repositioned in Western group, where Aquileia joins them due to its preponderance toward the $\mathrm{u}>\mathrm{O}$ type of error, as well. Only Pannonia Superior remains properly part of Eastern group, while Augusta Vindelicorum, Aquincum, Carnuntum, Salona and Venetia-Histria can be grouped under the Eastern category only because of the lack of data or perhaps, if this is not just a statistical distortion, the lack of Western velar phenomena.

Regarding the palatal misspellings on Table 1, what we find is that in the early period Augusta Vindelicorum, Virunum, Aquileia, Pannonia Superior and VenetiaHistria belong to the more advanced Romance palatal group, Aquincum, Raetia and Pannonia Inferior accompany them due to their higher proportion of $/ \mathrm{i} />\mathrm{E}$ mistakes. Carnuntum, Salona, Noricum and Dalmatia are classified as 'itacizing' territories because of their higher share of /e/ > I type of errors.

In the later period (Table 2) all territories become part of the advanced Romance palatal group, except Noricum which remains an 'itacizing' province, and the city of Aquincum, which has but one occurrence of unstressed long /e:/ > I mistake, making this classification statistically very dubious.

The results of these analyses suggest that most of the Alps-Danube-Adria region had an advanced palatal vowel system, which was increasingly Romance over time, while the velar system was predominantly Eastern or Southern Italian type in the 1 st-3rd centuries, but during the course of the 4th-7th centuries, half of the examined territories developed a Western Romance vowel system, especially in the rural areas and in the parts further from Italy.

\section{TYPOLOGY OF THE CONSONANT SYSTEM OF VULGAR LATIN}

For the review of the consonant system, we examine the statistics of the most characteristic Vulgar Latin consonant changes based on the data in Tables 4-5. The regional Vulgar Latin contrast samples of consonant misspellings, presented in Table 6, will help us again in the dialectal classification. ${ }^{9}$

${ }^{9}$ See n. 7. The statistics have been calculated according to the same methods as it was done for the vowels, and our regional Vulgar Latin samples don't include the data from the provinces of the AlpsDanube-Adria region. 


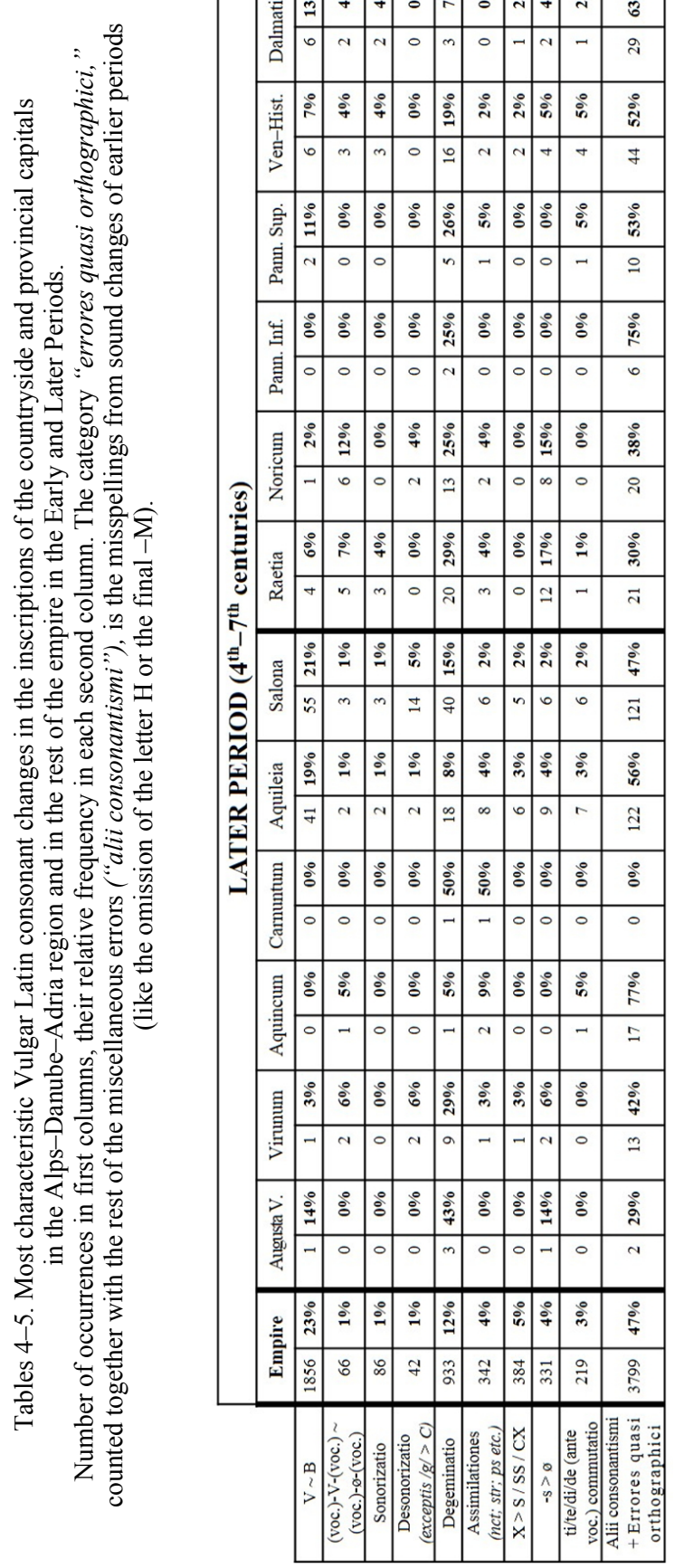

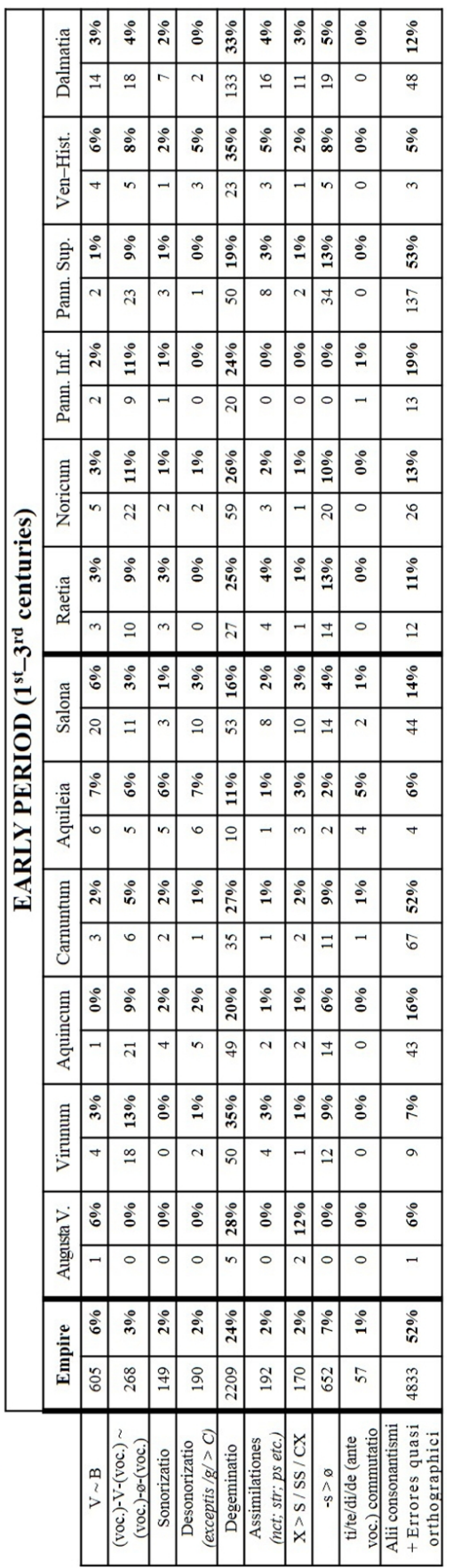


Table 6. Regional typology contrast samples of dialect-defining consonant misspellings in inscriptions from the 4th-9th centuries outside the Alps-Danube-Adria region.

Number of occurrences in the first column, their relative percentage in the second.

\begin{tabular}{|c|c|c|c|c|c|c|c|c|}
\hline \multirow[b]{2}{*}{$\mathrm{V} \sim \mathrm{B}$} & \multicolumn{2}{|c|}{ Western Romance } & \multicolumn{2}{|c|}{ Northern-Italian } & \multicolumn{2}{|c|}{ Southern-Italian } & \multicolumn{2}{|c|}{ Eastern Romance } \\
\hline & 124 & $8 \%$ & 35 & $10 \%$ & 181 & $29 \%$ & 9 & $5 \%$ \\
\hline $\begin{array}{c}(\text { voc. })-V-(\text { voc. }) \sim \\
(\text { voc. })-\varnothing-(\text { voc. })\end{array}$ & 12 & $1 \%$ & 1 & $0 \%$ & 9 & $1 \%$ & 2 & $1 \%$ \\
\hline Sonorizatio & 21 & $1 \%$ & 3 & $1 \%$ & 4 & $1 \%$ & 1 & $1 \%$ \\
\hline $\begin{array}{c}\text { Desonorizatio } \\
(\text { exceptis } / g />C)\end{array}$ & 14 & $1 \%$ & 3 & $1 \%$ & 3 & 0\% & 1 & $1 \%$ \\
\hline Degeminatio & 171 & $11 \%$ & 60 & $16 \%$ & 45 & $7 \%$ & 22 & $13 \%$ \\
\hline $\begin{array}{c}\text { Assimilationes } \\
(n c t ; \text { str; ps etc.) }\end{array}$ & 89 & $6 \%$ & 27 & $7 \%$ & 39 & $6 \%$ & 4 & $2 \%$ \\
\hline $\mathrm{X}>\mathrm{s} / \mathrm{ss} / \mathrm{CX}$ & 144 & $10 \%$ & 6 & $2 \%$ & 30 & $5 \%$ & 1 & $1 \%$ \\
\hline$-s>\varnothing$ & 57 & $4 \%$ & 17 & $5 \%$ & 43 & $7 \%$ & 13 & $8 \%$ \\
\hline $\begin{array}{c}\text { ti/te/di/de (ante } \\
\text { voc.) commutatio }\end{array}$ & 92 & $6 \%$ & 16 & $4 \%$ & 14 & $2 \%$ & 4 & $2 \%$ \\
\hline $\begin{array}{c}\text { Alii consonantismi } \\
+ \text { Errores quasi } \\
\text { orthographici }\end{array}$ & 774 & $52 \%$ & 198 & $54 \%$ & 266 & $42 \%$ & 111 & $66 \%$ \\
\hline
\end{tabular}

An important Vulgar Latin consonant change was the sonorization of voiceless plosives $(/ \mathrm{p} /, / \mathrm{t} /, / \mathrm{k} /)$. This characterizes the Romance dialects north and west of the La Spezia-Rimini or Massa-Senigallia line: the Gallo-Italian, Gallo-Romance and Ibero-Romance dialects voiced their intervocalic plosives, while the central and southern Italian dialects, Romanian and the extinct Dalmatian language didn't. ${ }^{10}$ The evidence of Romance languages, however, suggests that the reverse of this phenomenon, the desonorization, was - at least when not in word final position - usually an error due to hypercorrection, or a sign of a confusing change in the pronunciation of the plosives (some kind of lenition), rather than a permanent loss of the voiced quality. ${ }^{11}$ Our samples cannot show a significant difference in sonorization and desonorization between the regions, however, we find the smallest ratio of desonorization in Southern Italy $(0 \%)$, which might be an indication of relatively less disturbance in the degree of sonority of the plosives in general.

${ }^{10}$ See TAMÁs (n. 6) 66-68, or HeRman, J.: Vulgar Latin. Pennsylvania State University Press 2000, 45-47, and LopOrCARO, M.: Phonological Processes. In MAIDEN, M. ET AL. (eds): The Cambridge History of the Romance Languages I. Cambridge 2011, 154.

${ }^{11}$ Cf. GonDA: Changes (n. 4) 171. Romance languages inherited the Latin voiced consonants generally in voiced form, exceptions from under this rule are usually medieval Gallo-Italian, Gallo-Romance and Catalan developments, for example, the final obstruent devoicing in Gallo-Italian dialects, see BENINCÀ, P. - PARRY, M. - PESCARINI, D.: The Dialects of Northern Italy. In LEDGEWAY, A. - MAIDEN, M. (eds): The Oxford Guide to the Romance Languages. Oxford University Press 2016, 185-205; 190, and in Catalan, see Lloret, M.-R.: The Phonological Role of Paradigms: The case of insular Catalan. In Auger, J. - Clements, J. C. - VAnCE, B. (eds): Contemporary Approaches to Romance Linguistics: Selected Papers from the 33rd Linguistic Symposium on Romance Languages [Current Issues in Linguistic Theory 258]. Philadelphia 2004, 275-298, here 278-280. 
Degemination is also split by the Massa-Senigallia line: most of the Romance languages underwent a simplification of geminates, but Italian dialects south of the Massa-Senigallia line kept their double consonants. ${ }^{12}$ In our statistics consonant gemination is grouped also under the category of degemination as hypercorrection. ${ }^{13}$ Our samples confirm that the tendencies observed in modern Romance languages have their origin in the late Vulgar Latin, where we find that the Southern Italian sample has the lowest amount of degemination errors $(7 \%)$, while the other regions have a proportion between $11-16 \%$.

The next related phenomenon is the simplification of consonant clusters, which was less advanced in the East. ${ }^{14}$ This category includes all kinds of assimilations that point toward Romance developments, like the assimilation of $/ \mathrm{nd} /, / \mathrm{nm} / \mathrm{or} / \mathrm{gn} /$ to double $/ \mathrm{nn} /, \mathrm{rs} /$ or $/ \mathrm{ps} /$ to double $/ \mathrm{ss} /$. The assimilation of $/ \mathrm{ks} /$ is represented in Table 6 and in Tables 4-5 separately due to its large number so as not to obscure the proportion of other diverse forms of assimilations. After reviewing the statistics, we find with great satisfaction that the regional differences in the Romance languages are indeed inherited from this period: the Eastern sample gives us only 1\% of assimilation (and $2 \% / \mathrm{ks} /$ ), which is much lower than the 6-7\% registered in the other regions.

Another typical development in Romance languages was the loss of /-s/ at the end of words. ${ }^{15}$ Romance languages north of the Massa-Senigallia line originally retained the word ending /-s/, Southern and Eastern Romance lost it, and during later developments almost all Northern Italian dialects lost it, as well. Our regional samples mirror the later diversification of the Romance languages: while the Western and Northern Italian samples produce $4-5 \%$ of /-s/ drop respectively, the Southern Italian and Eastern samples contain a higher proportion, 7-8\%.

Since the palatalization of intervocalic /ti, di, ki, gi/ syllables was a pan-Romance phenomenon, with the exception of Sardinia, it is less helpful to look at the modern Romance languages for a point of reference here. However, it is a significant fact that palatalization in the Dalmatian language was incomplete, as it didn't undergo within the $/ \mathrm{ke} /$ syllable. This suggests that the forces of palatalization were less effective in the East. Accordingly, we find that in the Western and Northern Italian samples the rate of palatalization is $6-4 \%$ respectively, Southern Italian and Eastern samples show only $2 \%$.

Finally, an interesting distinguishing feature of Vulgar Latin dialects is the merge of the $\mathrm{V} \sim \mathrm{B}$ consonants, which was in correlation with the intervocalic $\mathrm{V}$-drop: ${ }^{16}$ the

\footnotetext{
${ }^{12}$ See VÄÄNÄNEN, V.: Introduction au latin vulgaire. Paris 1981, 58-60, TAMÁs (n. 6) 83-85 and LOPORCARO (n. 10) 150-153.

${ }^{13}$ Because degemination is always and in every territory at least two times more frequent than gemination.

${ }^{14}$ TAMÁs (n. 6) 74-83, Herman (n. 10) 47-48, and LoporCARO, M.: Syllable, Segment and Prosody. In MAIDEN, M. ET AL. (eds): The Cambridge History of the Romance Languages I. Cambridge 2011, 50-108, here 91-94.

${ }^{15}$ For a recent and exhaustive dialectological analysis of the omission of word-final /-s/, see ADAMIK, B.: The Problem of the Omission of Word-final -s as Evidenced in Latin Inscriptions. GraecoLatina Brunensia 22.2 (2017) 5-21.

${ }^{16}$ ADAMIK, B.: On the Vulgar Latin Merger of $/ \mathrm{b} /$ and $/ \mathrm{w} /$ and Its Correlation with the Loss of Intervocalic /w/: Dialectological Evidence from Inscriptions. Pallas 103 (2017) 25-36.
} 
Ibero-Romance and Southern Italian Romance dialects show a merger of the Latin $/ \mathrm{w} /$ and $/ \mathrm{b} /$ consonants, the Eastern Romance and Gallo-Italian dialects don't. ${ }^{17} \mathrm{We}$ find indeed that the Southern Italian sample has the highest proportion of $\mathrm{V} \sim \mathrm{B}$ errors $(29 \%)$ and the Eastern Romance sample has the lowest (5\%). However, it goes against our expectations that in the Western Romance sample it is only moderately higher $(8 \%)$ than in the East, and that in the Northern Italian sample it is higher $(10 \%)$ than in the Western, when it should be definitely lower than the Western. If we make a recounting of data in this category but only in the Hispanic provinces (Lusitania, Tarraconensis and Baetica), we get $9 \%$ for $\mathrm{V} \sim \mathrm{B}$ merger and $0 \%$ for the intervocalic $\mathrm{V}$ drop, which is not much better. ${ }^{18}$ We can only hypothesize that the $/ \mathrm{w} / \sim / \mathrm{b} /$ merger became more intensive in Hispania later. ${ }^{19}$ This leaves us with the picture that the $\mathrm{V} \sim \mathrm{B}$ merger was really intensive in the Southern Italian sample alone, it was moderate in the Northern Italian and Western Romance samples, and it was weak in the Eastern sample.

\section{CONSONANT SYSTEM IN THE ALPS-DANUBE-ADRIA PROVINCES}

This analysis of the regional samples demonstrated that the Vulgar Latin of the later period was already fragmented in a way that predicted the development of the Romance dialects which evolved in the specific region. We found only three problematic details: (1) the lack of salience in the degree of sonorization in the Western and Northern Italian samples, (2) the low degree of $\mathrm{V} \sim \mathrm{B}$ misspelling in the Western sample (we would expect more), and (3) the low degree of palatalization in the Southern Italian sample. We are now going to classify our 12 territories according to the parameters of our Romance regional typology samples, and we set up the criteria with consideration to the testimony of the modern Romance languages. All percentages from the Alps-Danube-Adria region that are used in the following analyses are taken from Tables 4-5, where they appear together with exact number of data found in the inscriptions.

\subsection{Sonorization and desonorization}

Since we must establish some sort of criterion even if the typology samples aren't helpful for the classification regarding sonorization, we are going to classify a territory with 'intensive sonorization' if the proportion of sonorization and desonorization

${ }^{17}$ VÄÄNÄNEN (n. 12) 50-51 on intervocalic /w/ drop and 56-58 on B V fusion. Also compare TAMÁs (n. 6) 61-62 and HERMAN (n. 10) 45-47.

${ }^{18}$ That the degree of $\mathrm{V} \sim \mathrm{B}$ confusion was not as preeminent as we would expect - even though it was an ever increasing tendency - in the Hispanic provinces, it was confirmed by ADAMIK: On the Vulgar Latin Merger (n. 16). We can assume that the $/ \mathrm{w} / \sim / \mathrm{b} / \sim / \beta /$ merger known from modern Ibero-Romance was fully developed only in the early Middle Ages.

${ }^{19}$ Our data after the collapse of the empire are scarce, which means that even though we conducted the database search for data between the 4th-9th centuries, in reality, data after the 5th century are usually sporadic. 
combined meets the imperial average (Tables 4-5) at least, and the ratio of sonorization is higher than that of desonorization. We label a territory with 'intensive desonorization' if, under the same conditions, the reverse is true, or if the ratio of sonorization is not higher than of desonorization; and, finally, we label the territory with 'no change in sonority' if the proportion of sonorization and desonorization combined doesn't reach the imperial average.

After the examination of the data in Table 7, we can conclude that, in the $1 \mathrm{st}-$ 3rd centuries, Salona, Venetia-Histria, Aquileia and Aquincum belong to the intensively desonorizating' group, because they have at least $4 \%$ of misspellings indicating sonority change, and they have a lower ratio of sonorization than desonorization. We leave the question open for now what exactly "desonorization" means in their case, whether an actual devoicing of plosives or some sort of lenition which manifested in a spelling mistake as desonorization, but was not actually a desonorization. All the rest of the territories belong to the conservative group, either because of their lower proportions of sonorization plus desonorization data combined, or because of the complete lack of change in the sonority.

Tables 7-8. The proportions of spelling errors of sonorization and desonorization in the 1 st -3 rd and 4 th- 7 th c. AD.

\begin{tabular}{|c|c|c|c|c|c|c|c|c|c|c|c|c|c|}
\hline \multirow{2}{*}{$\begin{array}{c}\text { EARLY } \\
\text { PERIOD }\end{array}$} & \multirow{2}{*}{ Empire } & Aug. V. & Noric. & Carnun. & Pan. Inf. & Pan. Sup. & Dalmat. & Raetia & Virun. & Salona & Ven-Hist. & Aquileia & Aquinc. \\
\hline & & \multicolumn{8}{|c|}{ No change in sonority } & \multicolumn{4}{|c|}{ Intensive desonorizatio } \\
\hline Sonorizatio & $2 \%$ & $0 \%$ & $1 \%$ & $2 \%$ & $1 \%$ & $1 \%$ & $2 \%$ & $3 \%$ & $0 \%$ & $1 \%$ & $2 \%$ & $6 \%$ & $2 \%$ \\
\hline Desonorizat. & $2 \%$ & $0 \%$ & $1 \%$ & $1 \%$ & $0 \%$ & $0 \%$ & $0 \%$ & $0 \%$ & $1 \%$ & $3 \%$ & $5 \%$ & $7 \%$ & $2 \%$ \\
\hline Combined & $4 \%$ & $0 \%$ & $2 \%$ & $3 \%$ & $1 \%$ & $1 \%$ & $2 \%$ & $3 \%$ & $1 \%$ & $4 \%$ & $7 \%$ & $13 \%$ & $4 \%$ \\
\hline $\begin{array}{l}\text { Ratio of } \\
\text { sonorizatio }\end{array}$ & $50 \%$ & $0 \%$ & $50 \%$ & $75 \%$ & $100 \%$ & $100 \%$ & $100 \%$ & $100 \%$ & $0 \%$ & $25 \%$ & $29 \%$ & $46 \%$ & $50 \%$ \\
\hline
\end{tabular}

\begin{tabular}{|c|c|c|c|c|c|c|c|c|c|c|c|c|c|}
\hline \multirow{2}{*}{$\begin{array}{l}\text { LATER } \\
\text { PERIOD }\end{array}$} & \multirow{2}{*}{ Empire } & Aquinc. & Pan. Inf. & Pan. Sup. & Carnunt. & Aug. V. & Noricum & Virunum & Salona & Aquileia & Raetia & Dalm. & Ven-Hist. \\
\hline & & \multicolumn{9}{|c|}{ Intensive desonorizatio or no change in sonority } & \multicolumn{3}{|c|}{ Intensive sonorizatio } \\
\hline Sonorizatio & $1 \%$ & $0 \%$ & $0 \%$ & $0 \%$ & $0 \%$ & $0 \%$ & $0 \%$ & $0 \%$ & $1 \%$ & $1 \%$ & $4 \%$ & $4 \%$ & $4 \%$ \\
\hline Desonorizatio & $1 \%$ & $0 \%$ & $0 \%$ & $0 \%$ & $0 \%$ & $0 \%$ & $4 \%$ & $6 \%$ & $5 \%$ & $1 \%$ & $0 \%$ & $0 \%$ & $0 \%$ \\
\hline Combined & $2 \%$ & $0 \%$ & $0 \%$ & $0 \%$ & $0 \%$ & $0 \%$ & $4 \%$ & $6 \%$ & $6 \%$ & $2 \%$ & $4 \%$ & $4 \%$ & $4 \%$ \\
\hline $\begin{array}{c}\text { Ratio of } \\
\text { sonorizatio }\end{array}$ & $50 \%$ & $0 \%$ & $0 \%$ & $0 \%$ & $0 \%$ & $0 \%$ & $0 \%$ & $0 \%$ & $17 \%$ & $50 \%$ & $100 \%$ & $100 \%$ & $100 \%$ \\
\hline
\end{tabular}

In the later period, sonorization as a strong acting force starts to appear, so we set apart a category for 'intensive sonorization', and we classify both the 'no change' and the 'intensive desonorizatio' as conservative. Raetia, Dalmatia, which had a strong sonorizing tendency already in the previous period, and Venetia-Histria, which was strongly desonorizing previously, now lead in sonorization, while it remains a weak phenomenon in Salona as seen in Table 8, even weaker than it was in the 1 st-3rd centuries, decreasing from $25 \%$ to $17 \%$ (which we obtain by counting the ratio of its $1 \%$ sonorization to its $5 \%$ desonorization), while the Dalmatian countryside is still the leading center of voicing the Latin consonants within the region. Pannonia Inferior, Superior and Carnuntum, lose their sonorizing tendencies, Aquincum and Aquileia lose their preeminence in desonorization. Since most of our provinces 
don't show intensive sonorization, the Alps-Danube-Adria region resembles a Southern or Eastern Romance dialect from this point of view.

It is interesting to note the difference between Dalmatia countryside and its capital Salona, especially if we also take in consideration that the Dalmatian language will evolve in this area, which as an Eastern Romance language didn't show sonorization. The rural areas of Dalmatia aren't behaving as expected, while Salona is. The intensive desonorization in the inscriptions of Noricum, its capital Virunum and Salona was probably caused partly by hypercorrection and partly by an inherent tendency of desonorization in our examined area which might later manifest itself in the final obstruent devoicing characteristic of Gallo-Romance, Rhaeto-Romance and Gallo-Italian dialects. ${ }^{20}$

\subsection{Degemination}

It is more difficult to choose a criterion based on which we could define a territory as intensively degeminating, because both the all-empire and the provincial proportions are very different in the early and in the later period, and we have regional typology samples only for the later period. Therefore we rule that the imperial average will serve in this position, because the late period imperial average in degemination $(12 \%)$ is approximately the dividing line between the regional contrast samples, as well (with $11 \%$ the Western sample was categorized as 'more intensive'): territories which produce at least the proportion of the imperial average will be labeled with 'intensive degeminatio', the rest with 'weak degeminatio'.

After observing the percentages of degemination errors in Table 9, the territories that show lower percentage than the imperial average $(24 \%)$ are classified as weakly degeminating, akin to Southern or Italo-Romance dialects. With the exception of Aquileia, Salona, Pannonia Superior and Aquincum, the Alps-Danube-Adria region shows a high proportion of degemination, which marks the region as mostly Western Romance.

By looking at the figures of Table 10, we can see that the process of degemination remains invariably less productive in Aquileia and Aquincum, but in this later period the Dalmatian countryside seems to fall in this category as well, though the overall scarcity of data (of all error types) from Dalmatia compels us to be suspicious about any surprising turns. If the low proportion of degemination in Dalmatia is not caused by statistical distortion, then perhaps it's because the process of degemination has run its course in Dalmatia, and, after having done its work with success, other phonetic changes are becoming more active and statistically more significant. That the result of degemination must have been permanent in the area is also attested by the extinct Dalmatian Romance language which had only simple consonants.

Although the low number of data doesn't allow us to be confident about that either (the $40 \%$ of Pannonia Superior most certainly is a statistical distortion due to

${ }^{20}$ See n. 11. 
the low number of inscriptions), the countryside of Pannonia Inferior and Pannonia Superior also seem to be joining the territories with intensive degemination, and the entire region in general is moving toward degemination in this later period.

Tables 9-10. Proportions of spelling errors indicating degemination in the 1 st -3 rd and 4 th- 7 th c. AD.

\begin{tabular}{|c|c|c|c|c|c|c|c|c|c|c|c|c|c|}
\hline \multirow{2}{*}{$\begin{array}{l}\text { EARLY } \\
\text { PERIOD }\end{array}$} & \multirow{2}{*}{ Empire } & Aquileia & Salona & Pan. Sup. & Aquincum & Pan. Inf. & Raetia & Noricum & Carnuntum & Aug. V. & Dalmatia & Ven-Hist. & Virunum \\
\hline & & \multicolumn{4}{|c|}{ Weak degeminatio } & \multicolumn{8}{|c|}{ Intensive degeminatio } \\
\hline Degeminatio & $24 \%$ & $11 \%$ & $16 \%$ & $19 \%$ & $20 \%$ & $24 \%$ & $24 \%$ & $26 \%$ & $27 \%$ & $28 \%$ & $33 \%$ & $35 \%$ & $35 \%$ \\
\hline
\end{tabular}

\begin{tabular}{|c|c|c|c|c|c|c|c|c|c|c|c|c|c|}
\hline \multirow{2}{*}{$\begin{array}{r}\text { LATER } \\
\text { PERIOD }\end{array}$} & \multirow{2}{*}{ Empire } & Aquincum & Dalmatia & Aquileia & Salona & Ven-Hist. & Noricum & Pan. Sup. & Raetia & Virunum & Pan. Inf. & Augusta V. & Carnuntum \\
\hline & & \multicolumn{3}{|c|}{ Weak degeminatio } & \multicolumn{9}{|c|}{ Intensive degeminatio } \\
\hline Degeminatio & $12 \%$ & $5 \%$ & $7 \%$ & $8 \%$ & $15 \%$ & $19 \%$ & $23 \%$ & $26 \%$ & $32 \%$ & $33 \%$ & $40 \%$ & $44 \%$ & $50 \%$ \\
\hline
\end{tabular}

\subsection{Assimilations}

In the case of assimilation, we make a difference between the early and the later period. For the same reasons as in the case of degemination, we will use the imperial average as the dividing line in the early period: territories which produce at least as many assimilationes (nct; str; ps etc.) plus X > S / SS / CX combined as the imperial average and have at least an equal number of assimilationes (nct; str; ps etc.) as the imperial average, will be classified with the label 'intensive assimilatio', the rest with 'weak assimilatio'. In the later period, however, we can apply the threshold value from the regional typology samples, which was $6 \%$ assimilationes (nct; str; ps etc.) for a region to be classified as intensively assimilating with at least $2 \%$ of $\mathrm{X}>\mathrm{S} / \mathrm{SS} / \mathrm{CX}$. Therefore we label the territories which have at least a value of $8 \%$ assimilationes (nct; str; ps etc.) plus X > S / SS / CX combined where the proportion of assimilationes (nct; str; ps etc.) reaches at least the imperial average (4\%) with 'intensive assimilatio'.

Tables 11-12. Proportions of spelling errors indicating assimilation in the 1 st -3 rd and 4 th- 7 th c. AD.

\begin{tabular}{|c|c|c|c|c|c|c|c|c|c|c|c|c|c|}
\hline \multirow{2}{*}{$\begin{array}{c}\text { EARLY } \\
\text { PERIOD }\end{array}$} & \multirow{2}{*}{ Empire } & Pan. Inf. & Aug. V. & Aquincum & Carnuntum & Aquileia & Noricum & Salona & Virunum & Pan. Sup. & Raetia & Dalmatia & Ven-Hist. \\
\hline & & \multicolumn{6}{|c|}{ Weak assimilatio } & \multicolumn{6}{|c|}{ Intensive assimilatio } \\
\hline Assimilationes & $2 \%$ & $0 \%$ & $0 \%$ & $1 \%$ & $1 \%$ & $1 \%$ & $2 \%$ & $2 \%$ & $3 \%$ & $3 \%$ & $4 \%$ & $4 \%$ & $5 \%$ \\
\hline$x>5 / s S$ & $2 \%$ & $0 \%$ & $12 \%$ & $1 \%$ & $2 \%$ & $3 \%$ & $1 \%$ & $3 \%$ & $1 \%$ & $1 \%$ & $1 \%$ & $3 \%$ & $2 \%$ \\
\hline
\end{tabular}

\begin{tabular}{|c|c|c|c|c|c|c|c|c|c|c|c|c|c|c|}
\hline $\begin{array}{c}\text { LATER } \\
\text { PERIOD }\end{array}$ & \multirow{2}{*}{ Empire } & Carnuntum & Aquincum & Aquileia & Pan. Sup. & Noricum & Raetia & Virun. & Salona & Ven-Hist. & Dalmatia & Pan. Inf. & Aug. V. \\
\hline & & \multicolumn{2}{|c|}{ Intensive assimilatio } & \multicolumn{8}{|c|}{ Weak assimilatio } \\
\hline Assimilationes & $4 \%$ & $50 \%$ & $9 \%$ & $4 \%$ & $5 \%$ & $4 \%$ & $4 \%$ & $3 \%$ & $2 \%$ & $2 \%$ & $0 \%$ & $0 \%$ & $0 \%$ \\
\hline $\mathrm{X}>\mathrm{S} / \mathrm{SS} / \mathrm{CX}$ & $5 \%$ & $0 \%$ & $0 \%$ & $3 \%$ & $0 \%$ & $0 \%$ & $0 \%$ & $3 \%$ & $2 \%$ & $2 \%$ & $2 \%$ & $0 \%$ & $0 \%$ \\
\hline
\end{tabular}

The comparison of the numbers gives Salona, Virunum, Pannonia Superior, Raetia, Dalmatia and Venetia-Histria as the more advanced territories in respect to 
the intensity of their assimilation tendencies. It goes against the average tendency in the empire, since in this early period assimilation was a very rare phenomenon, see the average in the empire as $2 \%$ in Table 4 . Assimilation increases after the 3 rd century, and the status of most of the territories changes. All the territories that belonged to the intensive assimilation category in the early period, now move to the category of weak assimilation which is characteristic of the Eastern Romance dialects.

\subsection{Elimination of word final /-s/ in the early period}

Following the methodology we applied in the previous categories, the elimination tendencies of the final /-s/ will be classified as 'intensive' in the early period if it is at least as frequent as the imperial average, and in the later period, if it is more frequent than the highest threshold value of the weak /-s/ drop sample group, which is $5 \%$ (Northern Italian sample).

In Table 13, we can see the result of this classification in the early period: Venetia-Histria, Carnuntum, Virunum, Noricum, Raetia and Pannonia Superior are more intensively eliminating their word final /-s/, which makes them more similar to Southern and Eastern Romance languages.

Table 13-14. Proportions of errors indicating elimination of /-s/ at word ending in the $1 \mathrm{st}-3 \mathrm{rd}$ and 4 th- 7 th $\mathrm{c}$. AD.

\begin{tabular}{|c|c|c|c|c|c|c|c|c|c|c|c|c|c|}
\hline \multirow{2}{*}{$\begin{array}{l}\text { EARIY } \\
\text { PERIOD }\end{array}$} & \multirow[t]{2}{*}{ Empire } & Augusta V. & Pan. Inf. & Aquileia & Salona & Dalmatia & Aquinc. & Ven-Hist. & Carnun. & Virunum & Noricum & Raetia & Pan. Sup. \\
\hline & & \multicolumn{6}{|c|}{\begin{tabular}{|c|} 
Weak final /-s/ drop \\
\end{tabular}} & \multicolumn{6}{|c|}{ Intensive final /-s/ drop } \\
\hline$-s>\varnothing$ & $7 \%$ & $0 \%$ & $0 \%$ & $2 \%$ & $4 \%$ & $5 \%$ & $6 \%$ & $8 \%$ & $9 \%$ & $9 \%$ & $10 \%$ & $13 \%$ & $13 \%$ \\
\hline
\end{tabular}

\begin{tabular}{|c|c|c|c|c|c|c|c|c|c|c|c|c|c|}
\hline $\begin{array}{c}\text { LATER } \\
\text { PERIOD }\end{array}$ & Empire & Raetia & Noricum & Augusta V. & Virun. & Ven-Hist. & Aquileia & Dalmatia & Salona & Aquinc. & Pan. Inf. & Carnun. & Pan. Sup. \\
\cline { 2 - 11 } & & \multicolumn{3}{|c|}{ Intensive final /-s/ drop } & \multicolumn{6}{|c|}{ Weak final /-s/ drop } \\
\hline$-s>\emptyset$ & $4 \%$ & $17 \%$ & $15 \%$ & $14 \%$ & $6 \%$ & $5 \%$ & $4 \%$ & $4 \%$ & $2 \%$ & $0 \%$ & $0 \%$ & $0 \%$ & $0 \%$ \\
\hline
\end{tabular}

In the later period, Raetia, Noricum and Virunum can keep their status as intensively /-s/ eliminating territories, but Venetia-Histria, Carnuntum and Pannonia Superior fall behind into the weak group. Only Augusta Vindelicorum can increase its degree of /-s/ drop. All these data may point out that these Northern territories were in this period more similar to the Southern or Eastern Romance dialects, which poses a problem, because we would have expected them to be like Northern Italian or Western Romance in this period. Perhaps, as Adamik noted, ${ }^{21}$ this discrepancy is caused by the fact that the elimination of the /-s/ was not yet a fully developed process, and the tendencies were still versatile and instable.

\footnotetext{
${ }^{21}$ See ADAMIK: The Problem (n. 15).
} 


\subsection{Palatalization}

Regarding the palatalization of the $t i / t e / d i / d e$ syllables, our examined territories in the early period will also be split by the imperial average (1\%), territories meeting this threshold will be classified with the label 'intensive palatalization', and in the later period, a territory must have a higher proportion of palatalization than that in the Eastern regional sample (2\%) where it is supposed to have been a less intensive process.

Table 15-16. Proportions of errors indicating palatalization $t i / t e / d i / d e$ syllables in the 1 st-3rd and 4th-7th c. AD.

\begin{tabular}{|c|c|c|c|c|c|c|c|c|c|c|c|c|c|}
\hline $\begin{array}{c}\text { EARLY } \\
\text { PERIOD }\end{array}$ & \multirow{2}{*}{ Empire } & Raetia & Noricum & Augusta V. & Virun. & Ven-Hist. & Dalmatia & Aquinc. & Pan. Sup. & Pan. Inf. & Carnunt. & Salona & Aquileia \\
\cline { 3 - 12 } & & \multicolumn{8}{|c|}{ Weak palatalization } & \multicolumn{3}{|c|}{ Intensive palatalization } \\
\hline $\begin{array}{c}\text { t//te/di/de (ante } \\
\text { voc.) commutatio }\end{array}$ & $1 \%$ & $0 \%$ & $0 \%$ & $0 \%$ & $0 \%$ & $0 \%$ & $0 \%$ & $0 \%$ & $0 \%$ & $1 \%$ & $1 \%$ & $1 \%$ & $5 \%$ \\
\hline
\end{tabular}

\begin{tabular}{|c|c|c|c|c|c|c|c|c|c|c|c|c|c|}
\hline $\begin{array}{c}\text { LATER } \\
\text { PERIOD }\end{array}$ & \multirow{2}{*}{ Empire } & Noricum & Augusta V. & Virun. & Carnunt. & Pan. Inf. & Raetia & Dalmatia & Salona & Aquileia & Aquinc. & Pan. Sup. & Ven-Hist. \\
\cline { 3 - 13 } & & \multicolumn{8}{|c|}{ Weak palatalization } & \multicolumn{3}{|c|}{ Intensive palatalization } \\
\hline $\begin{array}{c}\text { ti/te/di/de (ante } \\
\text { voc.) commutatio }\end{array}$ & $3 \%$ & $0 \%$ & $0 \%$ & $0 \%$ & $0 \%$ & $0 \%$ & $1 \%$ & $2 \%$ & $2 \%$ & $3 \%$ & $5 \%$ & $5 \%$ & $5 \%$ \\
\hline
\end{tabular}

Pannonia Inferior, Carnuntum, Salona and Aquileia meet the criterion to be classified as intensively palatalizing in the early period: it is understandable if the most important urban centers, with the most diverse background of speakers, produce the most progressive Romance phenomena.

Later only Aquileia remains intensively palatalizing from the territories which were previously, and now it's accompanied by Aquincum, Pannonia Superior and Venetia-Histria. Our territories are predominantly weak in palatalization which can be considered an Eastern (Dalmatian) Romance feature.

\section{6. $V \sim B$ merger and intervocalic $V$ drop}

Finally, a territory of 'intensive $\mathrm{V} \sim \mathrm{B}$ confusion' must have a larger proportion of $\mathrm{V} \sim \mathrm{B}$ fusions than intervocalic $\mathrm{V}$-drops, and in the earlier period the value for the $\mathrm{V} \sim \mathrm{B}$ fusion must be equal or higher than the imperial average (6\%). In the later period it must be also at least $8 \%$, the proportion of $\mathrm{V} \sim \mathrm{B}$ fusions in the Western sample, the lowest value among the regional samples where Romance languages which inherited a significant merger of the original Latin $/ \mathrm{w} / \sim / \mathrm{b} /$ exist.

Our findings in Table 17 accurately prove the complementary distribution of $\mathrm{V} \sim \mathrm{B}$ confusion and the decrease of the loss of the intervocalic $\mathrm{V},{ }^{22}$ as the territories which were intensive in $\mathrm{V} \sim \mathrm{B}$ merger in the early period (Augusta Vindelicorum, Salona, Aquileia), remain intensive in the later period, as well, joined by Dalmatia and Pannonia Superior.

${ }^{22}$ ADAMIK: On the Vulgar Latin Merger (n. 16) demonstrated that the higher the relative frequency of the drop of the intervocalic $\mathrm{V}$ in a region, the lower the percentage of the $\mathrm{V} \sim \mathrm{B}$ confusion is there. 
Table 17. Proportions of errors indicating $\mathrm{V} \sim \mathrm{B}$ merger and the loss of intervocalic $\mathrm{V}$ in the $1 \mathrm{st}-3 \mathrm{rd}$ and 4 th- 7 th $\mathrm{c}$. AD.

\begin{tabular}{|c|c|c|c|c|c|c|c|c|c|c|c|c|c|}
\hline \multirow{2}{*}{$\begin{array}{c}\text { EARLY } \\
\text { PERIOD }\end{array}$} & \multirow{2}{*}{ Empire } & Aug. V. & Salona & Aquileia & Ven-Hist. & Dalmatia & Raetia & Noric. & Virun. & Pan. Inf. & Pan. Sup. & Carnuntum & Aquincum \\
\hline & & \multicolumn{3}{|c|}{ Intensive V B merger } & \multicolumn{9}{|c|}{ Weaker V B merger } \\
\hline $\mathrm{V} \sim \mathrm{B}$ merger & $6 \%$ & $6 \%$ & $6 \%$ & $7 \%$ & $6 \%$ & $3 \%$ & $3 \%$ & $3 \%$ & $3 \%$ & $2 \%$ & $1 \%$ & $2 \%$ & $0 \%$ \\
\hline Intervoc. $V^{\sim} \varnothing$ & $3 \%$ & $0 \%$ & $3 \%$ & $6 \%$ & $8 \%$ & $4 \%$ & $9 \%$ & $11 \%$ & $13 \%$ & $11 \%$ & $9 \%$ & $5 \%$ & $9 \%$ \\
\hline \multirow{2}{*}{$\begin{array}{c}\text { LATER } \\
\text { PERIOD }\end{array}$} & \multirow{2}{*}{ Empire } & Salona & Aquileia & Aug. V. & Dalmatia & Pan. Sup. & Ven-Hist. & Raetia & Virun. & Noricum & Pan. Inf. & Carnuntum & Aquincum \\
\hline & & \multicolumn{5}{|c|}{ Intensive $\mathrm{V}^{\sim} \mathrm{B}$ merger } & \multicolumn{7}{|c|}{ Weaker V B merger } \\
\hline $\mathrm{V} \sim \mathrm{B}$ merger & $23 \%$ & $21 \%$ & $19 \%$ & $14 \%$ & $13 \%$ & $11 \%$ & $7 \%$ & $6 \%$ & $3 \%$ & $2 \%$ & $0 \%$ & $0 \%$ & $0 \%$ \\
\hline Intervoc. $V^{\sim} \emptyset$ & $1 \%$ & $1 \%$ & $1 \%$ & $0 \%$ & $4 \%$ & $0 \%$ & $4 \%$ & $7 \%$ & $6 \%$ & $12 \%$ & $0 \%$ & $0 \%$ & $5 \%$ \\
\hline
\end{tabular}

\section{CONCLUSION}

These statistical analyses demonstrated that most of the territories in the Alps-DanubeAdria region are linguistically similar to each other. We made comparisons in $8-8$ categories in the early and the later periods, 16 categories in total. Venetia-Histria, Carnuntum and Pannonia Superior, Pannonia Inferior, Noricum and Virunum, Raetia and Augusta Vindelicorum are more often similar (in 9-15 categories) than different. At the other end of the spectrum, there are Salona and Dalmatia, Aquileia and Aquincum (similar in 10-11 categories). Out of all these, the countryside of Dalmatia, Venetia-Histria and Pannonia Superior (the "Danube-Adria" area) show the most mixed characteristics, therefore they probably had a transitional or intermediate variant of Vulgar Latin between the Latin of the Eastern and Southern provincial capitals of the region, Aquincum, Aquileia and Salona, and the Western territories of the region (the "Alps-Danube" area). Most of the Vulgar Latin phenomena of the region are reminiscent of Eastern Romance and Northern Italian characteristics, although with many exceptions. In its more developed, later period, the Latin of the Alps-Danube-Adria region could be described as a dialect, or collection of dialects, which has a vowel system between the Eastern and Western type and a similarly mixed degree of $/ \mathrm{w} / \sim / \mathrm{b} /$ merger (though more often weak), preserves the voiceless plosives and - in this period at least - the word ending /-s/, resists palatalization and assimilation, but undergoes intensive degemination. In general, the Vulgar Latin dialects of the Alps-DanubeAdria region are conservative and often not uniform, and tentatively can be divided to a Southeastern "Danube-Adria" area and a Western "Alps-Danube" area.

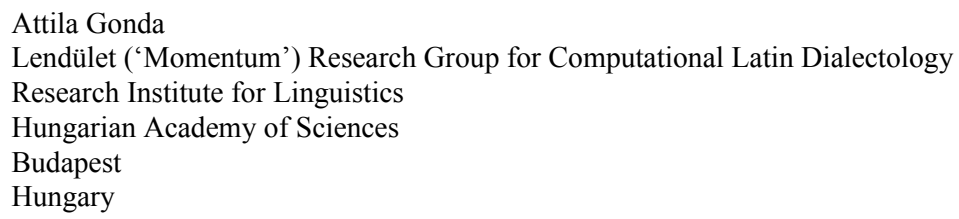

Open Access. This is an open-access article distributed under the terms of the Creative Commons Attribution 4.0 International License (https://creativecommons.org/licenses/by/4.0), which permits unrestricted use, distribution, and reproduction in any medium, provided the original author and source are credited, a link to the CC License is provided, and changes - if any - are indicated. (SID_1) 
